\title{
India rice export and virtual water trade
}

\author{
Uma Gowri M.* \\ Department of Agricultural Economics, Centre for Agricultural and Rural Development \\ Studies, Tamil Nadu Agricultural University, Coimbatore- 641003 (Tamil Nadu), India \\ Shivakumar K. M. \\ Department of Agricultural Economics, Centre for Agricultural and Rural Development \\ Studies, Tamil Nadu Agricultural University, Coimbatore- 641003 (Tamil Nadu), India \\ *Corresponding author. Email: drmumagowri@gmail.com
}

\section{Article Info}

https://doi.org/10.31018/

jans.v13iSI.2775

Received: March 22, 2021

Revised: April 17, 2021

Accepted: May 8, 2021

\section{How to Cite}

Uma Gowri, M. and Shivakumar, K. M. (2021). India rice export and virtual water trade. Journal of Applied and Natural Science, 13 (SI), 43 - 46. https://doi.org/10.31018/jans.v13iSI.2775

\begin{abstract}
The present study aimed to assess water footprint in the production and export of rice in India. From recent few years, the water footprint conception in full swing to inward detection around the world. The amplified attention in the water footprint has impelled the trade of commodities between countries. Water footprint in the rice field is a sign of water use that exhibits direct and indirect water usage in the rice field. Rice is an important food crop in India. It accesses the flows of water virtually between countries/regions of the world to illustrate the dependency of countries/regions on water resources with other countries/regions under diverse feasible futures. Hence, it is gaining consequence to calculate the water foot print in production as well as export of rice. The Indian rice production and export of rice was calculated by using international trade and domestic production data. The study results indicated that the global footprint of rice production was $235774 \mathrm{Mm}^{3}$ per ton which was $53 \%$ of green water footprint, $41 \%$ of blue water footprint and $6 \%$ of grey water footprint for 2018-19. The virtual water flowed in trade was 24354 $\mathrm{Mm}^{3} /$ year and the percolation was $16924 \mathrm{Mm}^{3} /$ year since rice is a more water consuming crop. The share of basmati and nonbasmati trade accounted was $16 \%$ and $42 \%$, respectively. Virtual water trade in rice can be minimized by exporting less water demand and high-value crops, proper water harvesting structures and other agronomic practices
\end{abstract}

Keywords: Economic gain, Export, Rice, Water footprint, Virtual water trade

\section{INTRODUCTION}

Rice is one of the important cereal crops and it serves a major role in feeding the population of the world, especially in South Asia and African countries (Cai and Sharma, 2017). Water used in the production of a product is called the 'virtual water' (Aeschbach and Gleeson, 2012). The Water Footprint (WF) of rice production and consumption is significant in the South Asian countries (Amarasinghe and Smakhtin, 2014). In these countries, WF is mostly rooted in the wet season and hence the contribution of scarcity of water is minimal. In rice production, the impact of environment of blue WF depends on the time and allocation of water use. Probably, majority of the cases, the green WF does not have any significant negative impact on the environment and economic level (Chukalla et al., 2015). If one country trades a product with water-intensive to another country, it trades water in the form of virtual
(Anup and Sekhon, 2014). In this way, some countries support other countries in their water needs Khandare et al., 2012). International virtual water flows for rice related to trade are quantified by multiplying trade volumes by their respective water footprints in the exporting countries (Naresh et al., 2017). Water footprint and percolation for production of rice in India were stands in the second position in major rice producing countries globally (De Fraiture and Wichelns, 2010), which were $2020 \mathrm{~m}^{3}$ and $1403 \mathrm{~m}^{3}$ per ton respectively and total national water footprint and percolation of water were 432.9 billion $\mathrm{m}^{3}$ per year. India was exported nearly 44 and 76 lakh tons of basmati and non-basmati rice respectively in 2018-19 (United States Department of Agriculture, 2018). Globally, the top five largest virtual water traders for rice products are Thailand $(9627$ $\mathrm{Mm}^{3}$ ), India $\left(5185 \mathrm{Mm}^{3}\right)$, USA $\left(3474 \mathrm{Mm}^{3}\right)$, Pakistan $\left(2923 \mathrm{Mm}^{3}\right)$ and China $\left(1296 \mathrm{Mm}^{3}\right)$ per year (Chapagain and Hoekstra, 2011). 
This paper quantifies the fresh rain water (green) and irrigation srface water (blue) needed to produce rice in India and quantum of water polluted (grey) from the application of fertilisers like nitrogen etc. Also, this study has made an attempt to calculate the percolation of rain and irrigation water in the rice field and the flow of virtual water through external rice trade.

\section{MATERIALS AND METHODS}

The data on the production, export of basmati and nonbasmati rice were obtained from FAO, APEDA, USDA and Ministry of Commerce and Industry, for the year 1995 to 2019. The water footprint for rice crop was calculated as follows:

\section{Water footprint}

Water footprint (WF) indicates the direct (green and blue) and indirect (grey) appropriation of freshwater resources which evaporates/evapo-transpires, incorporates into a product, contaminated and it is not returned to the same area where it was drawn (Kar et al., 2014).

\section{Blue water footprint}

It is the quantum of irrigated water from surface or groundwater except the water from rainfall for growing rice. Under unconstrained irrigated water condition, the whole need of scarcity of water for rice is met in the course of irrigation with the intention to execute the evapo-transpiration of rice crop $\left(\mathrm{PET}_{\mathrm{R}}\right)$ or requirement of water for rice crop $\left(\mathrm{CWR}_{\mathrm{R}}\right)$ and evaporation throughout in preparation of land for rice cultivation and thus usage of water by rice crop $\left(C W U_{R}\right)$ is equivalent to $\mathrm{PET}_{R}$ or $C W R_{R}$. Hence, for effusive irrigated rice crops, blue water ( $E T_{B L U E}$ ) or else the irrigation (IRR) requirement is equivalent to the $C W R_{R}$ minus $P_{E F F}$ and $\triangle S W$. If $P_{E F F}$ and $\triangle S W$ are equivalent or above that of $C W R_{R}$, the blue water requirement is zero.

The Blue Water Footprint $\left(\mathrm{WF}_{\mathrm{BLUE}}\right)$ refers to the share of the quantity of blue water consumed $\left(\mathrm{m}^{3} / \mathrm{ha}\right)$ throughout the period of rice production to the volume of the economic yield of rice crop (t/ha)

$\operatorname{BWF}_{\text {RICE }}\left(\mathrm{m}^{3} / \mathrm{t}\right)=$ Volume of blue water used in rice field $\left(\mathrm{m}^{3} / \mathrm{ha}\right) /$ Grain yield of the rice crop (t/ha) ...Eq. 1

\section{Green water footprint}

It is the ratio of loss of rain water and stored soil moisture as it does not become run off due to evaporation or evapo-transpiration during the rice growth to the quantity of economic rice yield ( $t / h a)$ produced. If rainfall is not received during rice growth period, the Profile Residual Soil Moisture of the rainy season (PSMC) may serve as a source of green water footprints.

$\operatorname{GNWF}_{\mathrm{RICE}}\left(\mathrm{m}^{3} / \mathrm{t}\right)=$ Volume of green water used in rice field $\left(\mathrm{m}^{3} / \mathrm{ha}\right) /$ Grain yield of the rice crop (t/ha) .....Eq. 2

\section{Grey water footprint}

It is defined as the quantity of freshwater required to assimilating the volume of pollutants in rice field based on ambient water quality standards

$\operatorname{GYWF}_{\mathrm{RICE}}\left(\mathrm{m}^{3} / \mathrm{t}\right)=$ Volume of grey water used in rice field $\left(\mathrm{m}^{3} / \mathrm{ha}\right) /$ Grain yield of the rice crop ( $\left.\mathrm{t} / \mathrm{ha}\right) \quad$..Eq.(3) The water footprint of rice is always expressed as the quantity of green, blue and grey water consumed during the rice growth period. Thus the total water footprint TWF $_{\text {RICE }}$ (Hoekstra and Chapagain, 2008; Hoekstra et al., 2011)

$\mathrm{TWF}_{\mathrm{RICE}}=\mathrm{GNWF}_{\mathrm{RICE}}+\mathrm{BWF}_{\mathrm{RICE}}+\mathrm{GYWF} \mathrm{FICE}_{\text {(volume/mass) }}$ Rice water foot print can be calculated by

$\mathrm{GNWF}_{\mathrm{RICE}}+\mathrm{BWF}_{\mathrm{RICE}}+\mathrm{GYWF}_{\mathrm{RICE}}\left(\mathrm{m}^{3} / \mathrm{ha}\right) /$ Economic yield of the rice crop (t/ha) $\quad$............. 4

$\mathrm{GNWU}_{\mathrm{RICE}}=$ Green water usage for rice crop,

$B W U_{\text {RICE }}=$ Blue water usage for rice crop,

$\mathrm{GYWU}_{\mathrm{RICE}}=$ Grey water usage for rice crop.

Crop Water Requirement is the total amount of water needed to compensate the evapo-transpiration (ET $\mathrm{RICE}_{\mathrm{C}}$ ) loss from the rice field from planting to harvest. Under unlimited water availability the total blue and green usage of water are equivalent to evapo-transpiration of

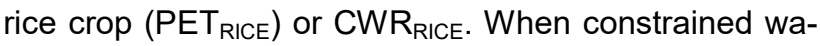
ter is available, BWU $\mathrm{RICE}+\mathrm{GNWU}_{\mathrm{RICE}}$ would be equivalent or less than total crop water requirement $\left(C W R_{\text {RICE }}\right)$ for the production of rice and thus, $C W U_{\text {RICE }}$ will be the actual evapo-transpiration of rice crop $\left(A E T_{\text {RICE}}\right)$.

\section{RESULTS AND DISCUSSION}

\section{Water footprint of Indian rice production}

Using the national water foot print of rice production, different water footprints of rice producing states of India, the present study as estimated the rice production to $235774 \mathrm{Mm}^{3}$ per ton (53\% green water footprint, $41 \%$ blue water footprint and $6 \%$ grey water footprint) for the year 2018-19. The volume of percolated rain and irrigation water in the rice field was $163839 \mathrm{Mm}^{3}$ per ton. (Fig. 1). Total water footprint and percolation of water used in the rice field was 1359 billion $\mathrm{m}^{3}$ which was reported by Chapagain and Hockstra (2011) estimated water foot print for production and export of rice in major rice producing countries at global level. Water footprint of Indian rice exports

International trade in rice during 2018-19 resulted in a total virtual water transfer of $24354 \mathrm{Mm}^{3}$ per year. The total percolation of rain and irrigation water footprint of Indian rice export was $9578 \mathrm{Mm}^{3}$ and $7346 \mathrm{Mm}^{3}$ per year. The total water footprint of Indian rice export (Fig. 2).

\section{Share of basmati and non-basmati rice exports of India}

The Five year average of basmati and non-basmati rice 
Uma Gowri, M. and Shivakumar, K.M. / J. Appl. \& Nat. Sci. 13 (SI), 43 - 46 (2021)

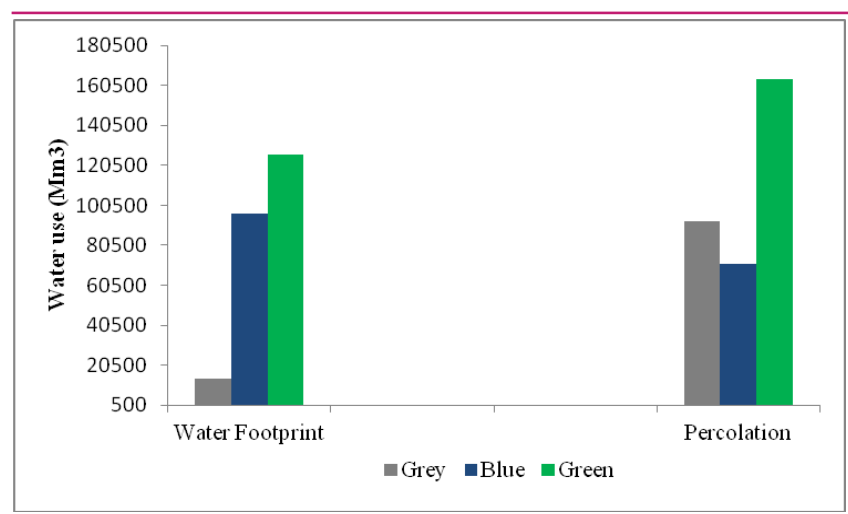

Fig. 1. Water footprint of India rice production (2018-19).

exports of India from 1995 to 2020 was calculated and is shown in Fig. 3. In the total trade of Indian rice, the contribution of basmati rice was increased from 1995 to 2015, which was accounted $16 \%$ and $42 \%$ in the respective years. In 2016-17, it was declined to $37 \%$ due to weak international demand of basmati rice in major importing countries. After 2017, basmati rice exports were witnessed to pick up in total Indian rice exports as the surge in demand in global markets.

\section{Indian rice exports (1995-2020)}

The trend of basmati and non-basmati rice export is given in Fig. 4. It could be seen that the export of nonbasmati rice decreased in the initial period of 1995 to 2005 and the export swirled the same volume up to 2010, after that it was increased. But in the case of non -basmati rice export, it was increased up to 2015, then the rate of increase in exports decreased due to decline in export demand and it is expected to increase in the coming years when the export orders would be received.

Rice is a staple food for three billion people (Kumar and Singh, 2005), especially in South Asian countries. In global level, rice provides chief calorie and nutrition directly and thus it makes an major food crop.

Trade in virtual water is a relevant concept accepted worldwide, considering countries are grappling with the

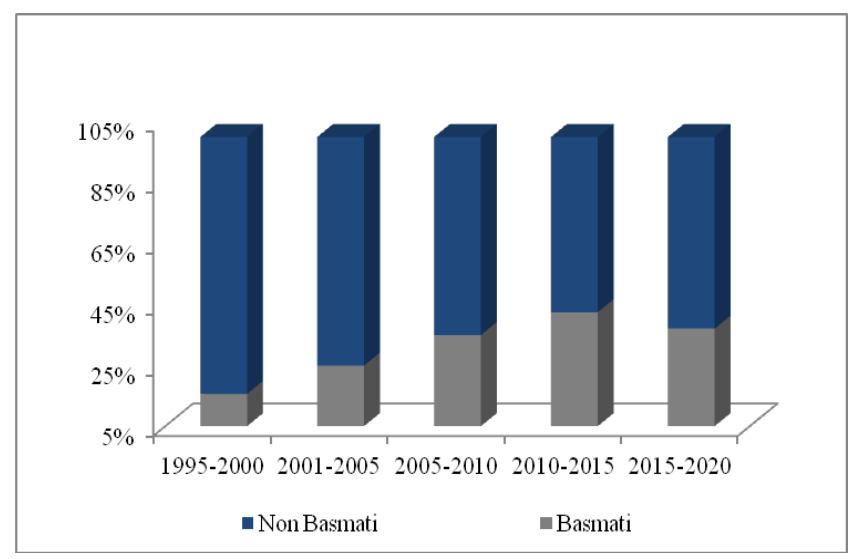

Fig. 3. Export of basmati and non basmati rice of India.

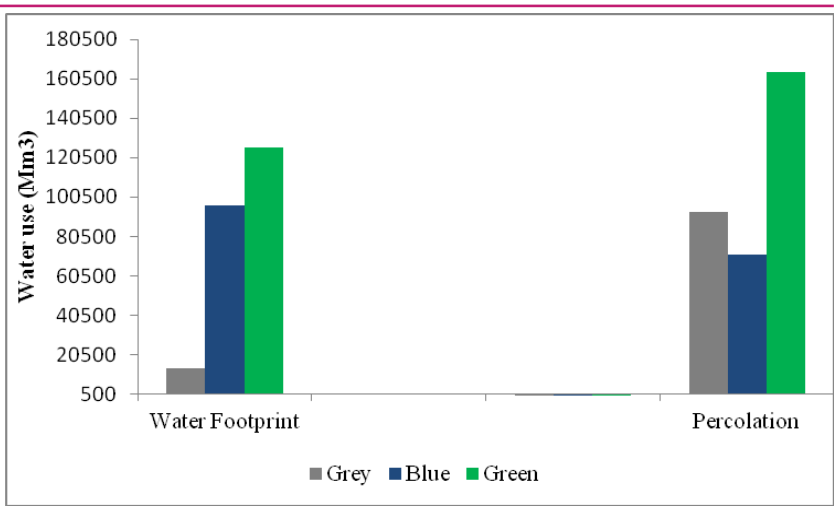

Fig. 2. Water footprint if Indian rice export (2018-19).

consequences of environmental sustainability (Ridoutt and Pfister, 2010). Depletion of groundwater, erratic rainfall, natural calamities like flood and drought are resulting in constrained economic ties among countries. India is a water-stressed country, water exploitation for production of rice to cater to exports significantly contribute to an increase in the virtual water trade. The surface water availability per person water would considerably be minimised from 1902 cubic metre in 2001 to 1401 cubic metre in 2025 and 1191 cubic metre in 2050 (Mishra et al., 2014). $85 \%$ of ground water used for agricultural and farming purposes remaining water is used for industrial and domestic purposes (Mamma, 2013). Hence, it is important to decide whether the contribution from export of water intensive crop like rice would be more than the commitment on the import dependence of less water consuming maize, pulses and oilseeds as the New Agricultural Export policy paves way encouraging states to go for import substitution wherever possible. The other way to reduce the export of water in virtual form from India is through the production of food crops by water efficient methods includes effective irrigation techniques, proper irrigation scheduling, suitable crop selection according to the land, climate conditions and using alternative sources of water for irrigation (Naresh et al., 2017). In the national level, less water demanded crops and as-

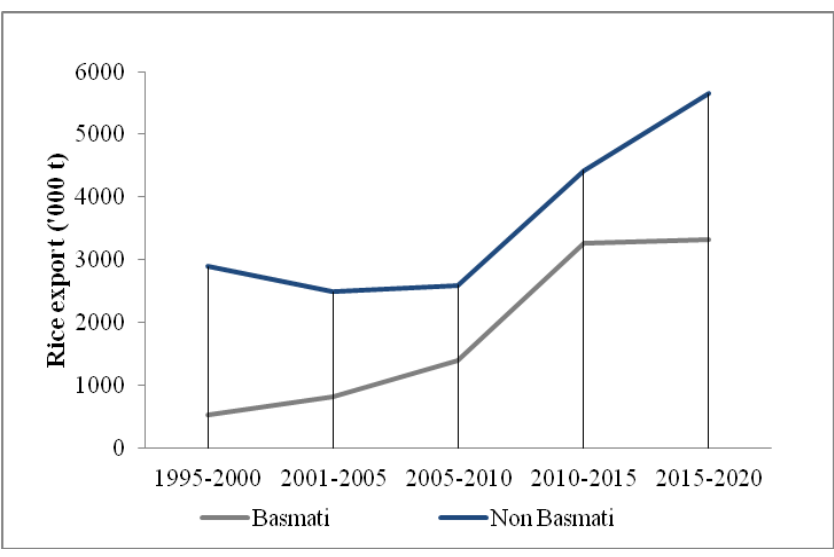

Fig. 4. India rice exports (1995-2020). 
tute mixing to be engaged to condense the virtual water export from India.

(Singh et al., 2014). This study provides ample evidence in calculating the water footprints of rice production and rice exports from India and helps the policymakers, scientists and extension officials to devise alternate cropping pattern to promote agricultural exports, implement suitable import substitution in order to strike a balance between export earnings and addressing the environmental issues.

\section{Conclusion}

The rice water footprint of production and export is fairly considerable in the world, especially in South Asian countries like India. There is almost an equivalent allocation of water usage in the form of green and blue water in the rice total water footprint at the world level. The green water footprint that is rain water consumed by the production of rice has a moderately stumpy opportunity cost compared to the evaporated irrigation water. In other words, blue water footprint from the rice field. The evaporated irrigation water from rice field depends on the location and time of the usage of water. From this study, it is evident that rice production mostly depends on irrigated water, which commonly causes greater impact per rice production unit. Further, in an international perspective, rice producing countries does not overheads the actual cost of water. Since the system of irrigation are subsidized and scarcity of water is never converted into a penalty, the economic costs of water are not enclosed in the form of rice price. The cost of water varies from countries/regions to countries/regions and depends on dry or wet rice production.

\section{Conflict of interest}

The authors declare that they have no conflict of interest.

\section{REFERENCES}

1. Aeschbach-Hertig, W. \& Gleeson, T. (2012). Regional strategies for the accelerating global problem of ground water depletion. Natural Geoscience, 5,853-861.

2. Amarasinghe, U.A. \& Smakhtin, V. (2014). Water productivity and water footprint: misguided concepts or useful tools in water management and policy?. Water International, 39, 1000-1017.

3. Anup Adhikari, \& Sekhon, M.K. (2014). Export of basmati rice from India: performance and trade direction. Journal of Agricultural Development and Policy, 24(1), 1-13.

4. Cai, X.L. \& Sharma, B.R. (2010). Integrating remote sensing, census and weather data for an assessment of rice yield, water consumption and water productivity in the Indo-Gangetic river basin. Agricultural Water Management, 97(2), 309-316.

5. Chapagain, A.K. \& Hoekstra, A.Y. (2011). The blue, green and grey water footprint of rice from production and consumption perspectives. Ecological Economics, 70, 749758.

6. Chukalla, A.D., Krol, M.S. \& Hoekstra, A.Y. (2015). Green and blue water footprint reduction in irrigated agriculture: effect of irrigation techniques, irrigation strategies and mulching. Hydrology and Earth System Sciences, 19, 4877-4891.

7. De Fraiture, C. \& Wichelns, D. (2010). Satisfying future water demands for agriculture. Agricultural Water Management, 97, 502-511.

8. Kumar, V. \& Jain, S.K. (2011). Export and import of virtual water from different states of India through food grain trade. Hydrology Research, 42, 2-3.

9. Hoekstra, A.Y. \& Chapagain, A.K. (2008). Globalization of water: sharing the planet's freshwater resources. Blackwell Publishing. Oxford, U.K.

10. Hoekstra, A.Y., Chapagain, A.K., Aldaya, M.M. \& Mekonnen, M.M. (2011). The water footprint assessment manual: setting the global standard, Earthscan, London, UK. p203.

11. Kar, G., Singh, R., Kumar, A. \& Sikka, A.K. (2014). Farm level water footprints of crop production: concept and accounting. Bulletin 67, Directorate of Water Management, Indian Council of Agricultural Research, Chandrasekharpur, Bhubaneswar, India.

12. Kumar, N.D. \& Singh, O.P. (2005). Virtual water in global food and policy making: is there a need for rethinking? Water Resources Management, 19, 759-789.

13. Mamma Sawaneh. (2013). Analysis of rice production instability in Southeast Asian Countries. Asian Journal of Agriculture and Rural Development, 3(10), 688-696.

14. Mishra, P., Debnath, M.K., Vishwajith, K.P., Basavanneppa, B.B. \& Sahul, P.K. (2014). Modeling and instability analysis of rice in India and their yield sustainability. Indian Journal of Science Research and Technology, 2(5), 73 $-81$.

15. Ridoutt, B.G. \& Pfister, S. (2010). A revised approach to water foot printing to make transparent the impacts of consumption and production on global freshwater scarcity. Global Environmental Change, 20, 113-120.

16. Naresh, R.K., Timsina,J., Dwivedi, A., Kumar, V., Singh, V., Shukla, A.K., Singh, S.P. Gupta, R.K. (2017). Water footprint of rice from both production and consumption perspective assessment using remote sensing under subtropical India: A review. International Journal of Chemical Studies, 5(1), 343-350.

17. Singh, N., Dikshit, A.K., Reddy, B.S. \& Surendra Kuthe, B, (2014). Instability in rice production in Gujarat: a decomposition analysis. Asian Journal of Economics and Empirical Research, 1(1), 6-9.

18. United States Department of Agriculture, (2018). Major world crop areas and climatic profiles. World Agricultural Outlook Board, U.S. Department of Agriculture, Washington DC. 